УДК 347.73

DOI https://doi.org/10.32849/2663-5313/2020.8.33

Тетяна Татарова,

канд. юрид. наук, докторант

Національної академї внутрішніх справ

\title{
ЩОДО ПИТАННЯ ВИЗНАЧЕННЯ ФІНАНСОВОГО ТА ПОДАТКОВОГО КОНТРОЛЮ
}

У статті мова йде про різні погляди дослідників на значення фінансового та податкового контролю. Також указується на загальне визначення терміна «контроль», який поділяється за об'єктами, суб'єктами і сферами на державний, відомчий, виробничий тощо. Розглядаються погляди дослідників з приводу сутності контролю в галузі виконавчої влади. Мова йде також про встановлення об'єкта фінансового контролю (фінансові показники діяльності суб'єктів господарювання всіх форм власності), фактичного об'єкта фінансового контролю (увесь прочес господарської діяльності), зазначається, що ией контроль пов'язаний із контрольною функиією фінансів. Наводяться думки науковиів щодо визначення терміна «фінансовий контроль», зауважується на вдалому визначенні А. Юхимчука із иього приводу. Зазначається, шо фінансовий контроль має на меті виявлення відхилень від прийнятих стандартів і порушень законності, ефективності та економії витрачання матеріальних ресурсів тошо. Розглядаються погляди на зміст фінансового контролю науковиів: Е. Вознесенсько$2 о$ (діяльність державних і громадських органів з перевірки обгрунтованості використання коштів), М. Малеїна (діяльність фінансових та інших організаиій, спрямована на забезпечення фінансової, податкової тощо дисцилліни), Н. Хімічевої (контроль за законністю дій у галузі утворення, розподілу й використання грошових фондів держави та місиевого самоврядування), Л. Савченко й інших. Розглядається фінансовий контроль у двох аспектах (діяльність спеціальних органів і невід'ємний елемент управління фінансами), визначається предмет державного фінансового контролю. Акиентується увага на тому, що залежно від суб'єктів здійснення фінансового контролю головну роль у процесі відіграє державний фінансовий контроль. Окрім того, визначається роль податкового контролю як частини державного фінансового контролю. Зроблено висновок, що під фіскальним контролем варто розуміти один із видів державного фінансового контрою, шо здійснюється через спечіально визначені органи контролю, який спрямований на управління й реалізацію державної податкової та митної політики, державної політики з адміністрування єдиного внеску, а також державну політику у сфері боротьби з правопорушеннями в указаних сферах, забезпечення контролю за надходженнями до бюджетів і державних цільових фондів податків, зборів, митних та іниих платежів.

Ключові слова: фіскальна політика, контроль, фінансовий контроль, податковий контроль, фіскал.

Постановка проблеми. Сучасна наука визначила відносно сталий перелік ознак будь-якої держави. Серед них, звісно, постає організація власної економіки, фінансової системи, а також установлення податків. Звісно, без організації ефективної системи податків і накопичення, відповідно, дохідної частини бюджету неможливе нормальне функціонування всього державного апарату й держави загалом. Наша держава перебуває в процесій постійних змін і реформ, спричинених зовнішньополітичним вектором євроінтеграції. Однією 3 важливих сфер реформування є фіскальна політика України, оскільки від цього залежить багато в чому матеріальне забезпечення загальнодержавного кошторису, що впливає на рівень соціальних стандартів тощо (високий рівень яких у країнах СС у пріоритеті). Ефективна фіскальна політика неможлива без такого елементу, як фінансовий і податковий контроль. Уважаємо, отже, проблематику встановлення дефініції та змісту понять «фінансовий» і «Податковий» контроль актуальним об'єктом наукового дослідження.

Проблемою характеризування термінів «фінансовий контроль», «податковий контроль» займалися такі дослідники: О. Андрійко, Л Гуцаленко, Є. Калюга, Н. Маринів, Л. Савченко й інші.

| Метою статті $є$ аналіз сутності фінансового та податкового контролю.

Виклад основного матеріалу. У правовій, а також літературі інших галузей знань наводять різні тлумачення дефініції «контроль». У юридичній енциклопедії Ю. Шемшученка визначається так: контроль «(франц. controle - перевірка, від старофранц. contrerole - список, що має дублікат для 
перевірки) - перевірка виконання законів, рішень тощо. $Є$ однією з найважливіших функцій державного управління. За об'єктами, суб'єктами і сферами поділяється на державний, відомчий, надвідомчий, виробничий тощо види контролю» [3].

Характеризуючи сутність контролю в галузі виконавчої влади, Д. Овсянко відзначає, що «уповноважені на те державні органи (законодавчих, виконавчих, судової гілок) і громадські організації, використовуючи організаційно-правові способи і засоби, з'ясовують, чи немає в діяльності підконтрольних органів виконавчої влади і їх посадових осіб яких-небудь відхилень від законності, а якщо такі є, то своєчасно їх усувати, відновлюючи порушені при цьому права, притягати винних до відповідальності, уживаючи заходи щодо запобігання порушенням законності й дисципліни» [11, с. 178].

Розгляд контролю за виконанням державного бюджету як підсистеми менеджменту держави потребує досліджувати його як єдину самостійну систему, що складається 3 трьох основних елементів - контролюючого суб'єкта, підконтрольного об'єкта й контрольних дій.

У науковій літературі найчастіше вживають поняття «фінансовий контроль». Безпосередньо об'єктом фінансового контролю $€$ фінансові показники діяльності суб'єктів господарювання всіх форм власності, але фактичним об'єктом фінансового контролю $є$ весь процес виробничо-господарської діяльності, оскільки вони або регламентують процес формування, розподілу, перерозподілу й використання фінансових ресурсів, або відображають результативність їх кругообігу.

Фінансовий контроль органічно пов'язаний із контрольною функцією фінансів, призначення якої в тому, щоб створити економічні умови для здійснення контролю за розподілом централізованих i децентралізованих грошових фондів з метою забезпечення фінансових потреб відповідних суб'єктів. М. Бєлуха визначає контроль як «завершальну стадію процесу управління, серцевиною якої є механізм зворотного зв'язку» [4, с. 3]. За визначенням Є. Калюги, під фінансовим контролем розуміють спостереження, визначення та виявлення фактичного становища фінансових показників діяльності порівняно із заданими [8].

А. Юхимчук наводить вдале, на нашу думку, визначення фінансового контролю, під яким розуміе сукупність форм, методів, прийомів здійснення ревізій і перевірок фінансово-господарської діяльності підпри- ємств, об'єднань, організацій, установ; законності операцій 3 формування, розподілу та використання централізованих і децентралізованих фондів коштів, збереження власності; правильності й своєчасності виконання фінансових зобов'язань перед бюджетом, державними позабюджетними фондами; постановки бухгалтерського обліку й достовірності звітності [16, с. 29-30.].

Відповідно до ст. 1 Лімської декларації керівних принципів контролю, прийнятої IX Конгресом Міжнародної організації вищих контрольних органів у 1977 році, організація контролю є обов’язковим елементом управління суспільними фінансовими коштами, оскільки таке управління передбачає відповідальність перед суспільством [1].

Контроль - не самоціль, а невід'ємна частина системи регулювання, метою якої $€$ виявлення відхилень від прийнятих стандартів і порушень принципів, законності, ефективності й економії витрачання матеріальних ресурсів на якомога більш ранній стадії, щоб мати можливість прийняти коригувальні заходи, в окремих випадках притягнути винних до відповідальності, отримати компенсацію за заподіяний збиток або здійснити заходи щодо запобігання порушенням або зменшення таких порушень у майбутньому.

На думку Е. Вознесенського, фінансовий контроль - це діяльність державних і громадських органів, яка полягає в перевірці обгрунтованості процесів формування й використання централізованих і децентралізованих коштів [6, с. 55]. М. Малеїн розглядає фінансовий контроль як діяльність фінансових, кредитних і господарських органів (організацій), що регулюється нормами права, спрямована на забезпечення фінансової, бюджетної, податкової, кредитної, розрахункової та касової дисциплін у процесі виконання планів і полягає у перевірці законності, обгрунтованості й раціональності грошових витрат [9, с. 103]. Н. Хімічева вважає, що «фінансовий контроль - це контроль за законністю дій у галузі утворення, розподілу й використання грошових фондів держави та суб'єктів місцевого самоврядування 3 метою ефективного соціально-економічного розвитку країни в цілому та окремих регіонів» [14, с. 123].

Як один із видів фінансової діяльності держави щодо перевірки застосування встановлених законодавством методів контрольної діяльності, законності й раціональності дій суб'єктів господарювання в процесі створення, розподілу та використання грошових фондів держави визнає контроль Л. Савченко [13, с. 40-41]. 
Фінансовий контроль можна розглядати у двох аспектах: 1) як чітко регламентовану діяльність спеціальних контролюючих органів за дотриманням фінансового законодавства та фінансової дисципліни всіх економічних суб'єктів; 2) як невід'ємний елемент управління фінансами та грошовими потоками для забезпечення доцільності й ефективності фінансових операцій [15, с. 23].

Варто зазначити, що предметом державного фінансового контролю $є$ власне фінансово-господарська та розпорядча діяльність підконтрольних об'єктів у частині формування, володіння, використання й відчуження коштів та інших активів, що належать або мають належати державі, у тому числі за зобов'язаннями по податках, обов'язкових платежах і відрахуваннях до бюджету й позабюджетних фондів.

Необхідно підкреслити, що, незважаючи на значну кількість нормативно-правових документів у галузі державного фінансового контролю, сьогодні в Україні відсутній єдиний нормативно-правовий акт, що узагальнює структуру, суб'єкти та об'єкти державного фінансового контролю, що спричиняе низку протиріч і суперечностей у правовому полі регулювання державного фінансового контролю.

На нашу думку, фінансовий контроль передбачає наявність зворотних зв'язків, що виражаються в активному впливі контролю на раціональне використання фінансових ресурсів, в усуненні перешкод оптимальному функціонуванню всіх ланок фінансової системи.

Відповідно, залежно від суб'єктів, що здійснюють фінансовий контроль, головну роль у цьому процесі надають державному фінансовому контролю. Варто зазначити, що вітчизняним законодавством визначення категорії «державний фінансовий контроль» не регламентоване.

Так, податковий контроль є частиною державного фінансового контролю, сутність якого полягає в установленні фактичного стану дотримання вимог чинного податкового законодавства на підконтрольному об'єкті. Він спрямований на забезпечення законності, фінансової дисципліни та раціональності в ході формування, розподілу, володіння, використання й відчуження активів, що належать державі, а також використання коштів, що залишаються в суб'єкта фінансових правовідносин у зв'язку з наданими пільгами за платежами до бюджетів, державних позабюджетних фондів і кредитів, отриманих під гарантії Кабінету Міністрів України [7, с. 30].

У науковій і спеціальній літературі значна увага приділена саме дослідженню сутності й ролі податкового контролю. І в більшості випадків ототожнюють поняття «податкового» й «фіскального» контролю, хоча це не зовсім коректно.

Одні вчені розглядають податковий контроль як один із видів фінансового контролю, що являє собою діяльність спеціально уповноважених суб'єктів стосовно особливого об'єкта, спрямовану на забезпечення виконання податкового законодавства платниками податків, податковими агентами й іншими суб'єктами, які забезпечують виконання податкового обов'язку платників податків, установлення та притягнення в разі необхідності до відповідальності винних осіб [10, с. 9-10]. Інша група вчених зазначає, що податковий контроль виконує одну з функцій державного управління та спеціалізований державний фінансовий контроль. Його сутність полягає не лише в перевірці дотримання податкового законодавства, а й у перевірці правильності розрахунків, повноти і своєчасності сплати податків і зборів, а також у встановленні виявлених порушень [2].

Деякі вчені розглядають податковий контроль як спеціалізований надвідомчий контроль, як установлену законодавством сукупність методів керівництва компетентних органів, що забезпечують дотримання податкового законодавства, правильність обчислення, повноту і своєчасність унесення податку до бюджету [12]

За своєю сутністю наявні розбіжності щодо дефініції понять незначно впливають на значення й застосування. Але поряд із тим поняття «фіскального» контролю починає поширюватися в науковій літературі та деяких нормативно-правових документах.

Етимологія походження слова «фіск» розкривається через родове поняття «державна казна», від французького fisc, у латині fiscus - це «корзина, у тому числі для грошей, державна казна», у німецькій мові Fiskus, dem Fisco мають такі самі значення. Перше значення слова фіскал або обер-фіскал - назва посадової особи, яка, можливо, має походження від польського fiska - юрист, прокурор або латинського fiscalis - казенний.

У тлумачних словниках віднаходимо такі значення слів «фіск», «фіскал» $\mathrm{i}$ «фіскальний»:

1. фіск - у Стародавньому Римі це була імператорська скарбниця, у буржуазній юриспруденції - державна скарбниця;

2. фіскал - у дореволюційній Росії вживався як урядовець, що здійснював нагляд за діяльністю адміністративних установ та осіб з метою виявлення порушень законів та інтересів державної скарбниці - фіску;

3. фіскальний - походження має від латинського fiscalis «казенний, казначейський» або від fiscus «корзина, каса; казна»; 
4. фіск - у Давньому Римі також означало військову касу, де зберігаються гроші, призначені до видачі. 3 часу Августа фіском стала називатися приватна каса імператора, що перебувала у веденні чиновників і поповнювалася доходами з імперських провінцій та іншими засобами. Фіском також називалося й усе імперське управління. 3 IV століття фіск - це єдиний загальнодержавний фінансовий центр Римської імперії, куди стікалися всі види доходів і зборів, а також звідси отримувалися вказівки про чеканку монет, порядок збирання податків, здійснювалися виплати тощо;

5. фіскал - при Петрі I це був чиновник, що наглядав за законністю дій установ та осіб в основному у фінансовій і судовій сферах; відповідно, фіскальний - це пов'язаний із фіскалом або характерний для фіскала.

Як відмічають науковці, категорія фіску широко застосовується не лише в давньоримській і середньовічній літературі, а й у юридичній науці нового часу. Як приклад можна навести цитату відомого німецького вченого О. Майера: «Фіск - це сама держава, що розуміється з одного певного боку, ... відзначають, що фіск - це держава як суб'єкт у відносинах 3 приводу державного майна» [5].

\section{Висновки}

Отже, сьогодні для уникнення дублювання повноважень податкових і митних органів та інших дотичних державних структур, які виконують функції контролю, зниження рівня бюрократизації та підвищення ефективності роботи, доцільно впровадити не лише на науковому рівні поняття «фіскальний контроль», а й у практичну його площину. На нашу думку, доцільно в окремих аспектах ототожнювати визначення «фіскального» контролю й «податкового» контролю. Отже, під фіскальним контролем варто розуміти один із видів державного фінансового контрою, що здійснюється через спеціально визначені органи контролю, який спрямований на управління й реалізацію державної податкової та митної політики, державної політики з адміністрування єдиного внеску, а також державну політику у сфері боротьби з правопорушеннями в указаних сферах, забезпечення контролю за надходженнями до бюджетів і державних цільових фондів податків, зборів, митних та інших платежів.

\section{Список використаних джерел:}

1. Лімська Декларація керівних принципів контролю, прийнята IX Конгресом Міжнародної організації вищих контрольних органів (INTOSAI) y 1977 році. URL: https://zakon.rada.gov.ua/laws/ show/604_001 (дата звернення: 20.02.2020).

2. Административно-правовое регулирование экономических отношений / отв. ред. И.Л. Бачило, Н.Ю. Хаманева. Москва : МЗ-Пресс, 2001. $218 \mathrm{c}$.

3. Андрійко О.Ф. Контроль. Юридична енииклопедія : у 6 т. / редкол. : Ю.С. Шемшученко (голова редкол.) та ін. Київ : Укр. енцикл., 1998. URL: https://leksika.com.ua/10530412/legal/ kontrol (дата звернення: 20.02.2020).

4. Белуха Н.Т. Теория финансово-хозяйственного контроля. Киев : Выша школа, 1990. 278 с

5. Бєлих В.С., Вінницький Д.В. Податкове право Росії. Короткий навчальний курс. Київ, 2004

6. Вознесенский Э.Ф. Финансовый контроль в СССР. Москва : Юридическая литература, 1973. $134 \mathrm{c}$.

7. Гуцаленко Л.В., Дерій В.А., Коцупатрий М.М. Державний фінансовий контроль : навчальний посібник. Київ : ЦУЛ, 2009. 424 с.

8. Калюга Є.В. Фінансово-господарський контроль в системі управління. Київ : Ніка-Центр $2002,360 \mathrm{c}$.

9. Малеин Н.С. Кредитно-расчетные правоотношения и финансовый контроль. Москва : Наука, 1964. 152 с.

10. Маринів Н.А. Податкова перевірка як організаційно-правова форма реалізації податкового контролю : автореф. дис. ... канд. юрид. наук : 12.00.07. Харків, 2007. 20 с.

11. Овсянко Д.М. Административное право : учебное пособие для студентов юридических факультетов и институтов / отв. ред. проф. Г.А. Туманов. Москва : Юрист, 1995. 304 с.

12. Пономарев И.А. Налоги и налогообложение в Российской Федерации. Ростов-на-Дону : Феникс, 2001. 352 с.

13. Савченко Л.А. Правові проблеми фінансового контролю в Україні : монографія. Ірпінь : Академія ДПС України, 2001. 407 с.

14. Химичева Н.И. Финансовое право. 3-е изд. перераб. и доп. Москва : Юристъ, 2004. 749 с.

15. Эриашвили Н.Д. Финансовое право : учебник для вузов. Москва : ЮНИТИ-ДАНА, Закон и право, 2000. 606 с.

16. Юхимчук А. Система фінансового контролю - з глибин історії до нинішніх днів. Трибуна. 1999. № 1-2. C. 29-30. 
Tetiana Tatarova. To the issue of financial and tax control

The article deals with different viewes of researchers on the importance of financial and tax control. It also refers to the general definition of the term "control", which is divided by objects, entities and spheres into state, departmental, industrial and others. It points to the viewes of researchers about the essence of control in the field of executive power. It also refers to the establishment of the object of financial control (financial performance of economic entities of all forms of ownership), the actual object of financial control (the whole process of economic activity), it is stated that this control is related to the control function of finances. The study gives the opinion of scientists on the definition of the term "financial control", notes on the successful definition of A. Yukhimchuk in this regard. It is noted that financial control is aimed at detecting deviations from the adopted standards and violations of the legality, ef ficiency and cost savings of material resources, etc. Views on the content of financial control of scientists E. Voznesensky (this activity of state and public bodies to check the reasonableness of the use of funds), M. Malein (activities of financial and other organizations aimed at providing financial, tax, etc. discipline), $N$. Khimicheva (control of legality actions in the field of formation, distribution and use of state funds and local self-government), L. Savchenko and others. The article deals with financial control in two aspects (the activities of special bodies and an integral element of financial management), defines the subject of public financial control. Attention is drawn to the fact that, depending on the subjects of financial control, the main role in the process is played by the state financial control. In addition, the role of tax control as part of public financial control is determined. It is concluded that fiscal control should be understood as one of the types of state financial control carried out through specially designated control bodies, which is aimed at managing and implementing state tax and customs policy, state policy on single contribution administration, and state policy in the field of control with offenses in these areas, ensuring control over revenues to budgets and state trust funds of taxes, fees, customs and other payments.

Key words: fiscal policy, control, financial control, tax control, fiscal. 